\title{
European family law - Introduction to the book set
}

\section{Jens M. Scherpe}

The central aim of this book set is to inform the reader about the emerging European family law. As this area is in a surprising state of flux, some of the details provided might be out of date by the time the books are read. But since the aim of the set is not to provide detailed knowledge but rather to focus on underlying principles and highlight certain developments, in the view of the authors this does not detract from its value. This set is intended to serve as a resource for anyone interested in family law in general and in European family law in particular, and does not purport to provide comprehensive answers to all the complex questions raised in this area of law. In many ways, therefore, it is meant to provide a starting point for research, which is indeed why all of the contributions not only contain a wealth of references in the footnotes but also a short list of suggested further reading in the respective topic at the end.

In many ways, putting together a book set on European family law was a daunting task. Not only is the definition of what a 'family' is increasingly undergoing changes in many jurisdictions, even what should be considered 'family law' is highly debated. If one adds 'European' into that mix, yet more questions arise. What is 'European' in this context? Does this comprise the entire continent, that is, should it go beyond the Member States of the European Union? To that the answer, at least for the purposes of this book set, is a clear 'yes'. As readers will have noted, the book set is called 'European Family Law' rather than 'European Union Family Law', and thus its scope extends beyond the borders of the European Union, and national reports on Russia, Switzerland and Turkey have been included in Volume II.

Many of my colleagues, particularly those involved in the teaching and research of European Union law, have suggested to me that this project was a complete absurdity, as there was no such thing as a 'European family law'. I was told that as there was no body, no institution that 
actually had the power, legislative or otherwise, to create (or worse, impose) a 'European family law', there could be no such thing. In addition, I was told by several colleagues on many occasions that family law is and should remain a purely national matter, as it is too deeply rooted in the social and legal traditions of the respective jurisdictions and is not susceptible at all to harmonisation or unification - or even meaningful comparison. While these views of course made a point (at least to some extent), I nevertheless disagreed. But perhaps the disagreement arose only from a misunderstanding of what 'European family law' actually is. If my colleagues were referring to a comprehensive European Family Law Code, then of course they were right. But the absence of such a code does not mean that there is presently no European family law at all. On the contrary, as this book set shows, there is without any doubt an emerging European family law, comprising principles shared across jurisdictions, and there are institutions and organisations shaping this law. This European family law is not comprehensive; it is selective, covering some areas but not others - but it is certainly there and it continues to grow. And it is this European family law that this book set is about.

The first volume looks at the 'impact of institutions and organisations' on the emerging European family law and thus at what in Volume IV will be termed 'institutional European family law'. First and foremost, these institutions are the European Union and the Court of Justice of the European Union (Chapter 1 by Geert De Baere and Kathleen Gutman) and the European Court of Human Rights (Chapter 2 by Dagmar Coester-Waltjen). While the European Union has no direct competence to regulate national family laws, many legal acts of the European Union and decisions of the Court of Justice of the European Union establish 'minimum standards' for Member States in the area of their family law. The same is true of the growing body of case law of the European Court of Human Rights. The decisions of this court are of course only binding on the parties before it, but they nevertheless have a massive impact on all Contracting States, thus establishing minimum standards for often very specific areas of family law. In an increasingly 'globalised' world where families move between countries more and more, there is also increasing pressure on private international law, not only at the national level but also upon the private international law instruments of the European Union (Chapter 7 by Dieter Martiny) and the Hague Conference (Chapter 5 by Hannah Baker and Maja Groff). The impact of many such instruments, not only on the private international laws of the respective states but also on substantive family law, cannot be underestimated. The same undoubtedly is true of the work of the Council of Europe (Chapter 3 by Nigel Lowe) and the International Commission on 
Civil Status (Chapter 4 by Walter Pintens). The academic initiative of the Commission on European Family Law (CEFL) which, based on in-depth comparative studies, is drafting 'Principles of European Family Law', is also becoming influential (Chapter 6 by Katharina Boele-Woelki) and these Principles are increasingly taken into account when law reform is debated. Finally, the Christian faith is often seen as a 'basis' or at least a unifying factor of Europe and thus potentially, by extension, for European family law. Hence the impact of religion (even though, strictly speaking, religion is neither an institution nor an organisation) is considered in Volume 1 as well.

As mentioned at the beginning of this introduction, there is considerable debate on what 'family' or 'family law' is. That is why the overarching theme for the national reports presented in the second volume is that of "the changing concept of "family" and challenges for domestic family law'. These short national reports ${ }^{1}$ by necessity can only skim the surface of the respective national family laws, and they of course are not meant to provide a comprehensive description or analysis of these laws; rather they are supposed to give a snapshot of the development of family law in a changing world, divided into horizontal (legal relationships between adults), vertical (legal relationships between adults and children) and individual (name and gender identity) family law. In doing so, the existing differences between the jurisdictions become apparent as also do the similarities in development. So while the 'cultural restraints' argument - that national family laws are too embedded in their own legal culture to be susceptible to harmonisation - might hold true to a certain extent, certain common or emerging trends can be identified. Thus, as will be elaborated upon in Volume IV, an 'organically grown' European Family Law appears to be emerging, of course furthered by the developments described in Volume I.

In the third volume certain selected issues are looked at in a European perspective: marriage (Chapter 1 by Caroline Sörgjerd), divorce (Chapter 2 by Masha Antokolskaia), unmarried cohabitation (Chapter 3 by Joanna

1 On the Benelux Countries (Frederik Swennen), England and Wales (Gillian Douglas), France (Laurence Francoz Terminal), Germany (Dieter Martiny), Greece (Eleni Zervogianni), Hungary (Orsolya Szeibert), Ireland (Brian Sloan), Italy (Maria G. Cubeddu-Wiedemann), the Nordic Countries (Tone Sverdrup), Russia (Olga Khazova), Scotland (Kenneth McK Norrie), Slovakia (Gabriela Kubíčková), Slovenia (Barbara Novak), Spain and Catalonia (Albert Lamarca Marquès), Switzerland (Ingeborg Schwenzer and Tomie Keller) and Turkey (Esin Örücü). 
Miles), same-sex relationships (Chapter 4 by Ian Curry-Sumner), financial consequences of divorce (Chapter 5 by Jens M. Scherpe), the child's welfare (Chapter 6 by Rob George), parentage and surrogacy (Chapter 7 by Katarina Trimmings and Paul Beaumont), parental responsibility (Chapter 8 by Josep Ferrer-Riba), adoption (Chapter 9 by Claire FentonGlynn), and family law and older people (Chapter 10 by Jonathan Herring). These chapters cut across the topics and reports presented in the first and second volume of the book set, and show whether (and why) there is a European family law (or there are aspects of it) in the respective area, and, if so, to what extent.

The fourth volume, entitled 'The Present and the Future of European Family Law' and written by the editor of the first three volumes, contains a comparative summary and analysis, building on the other chapters of the book set. In doing so, a distinction is drawn between 'institutional' and 'organic' European family law. The former is perceived as the result of the institutional impact mainly discussed in Volume I but is of course of great significance for both Volume II and, especially, Volume III as well. The 'organic European family law' is the less well-defined, less tangible part of European family law that emerges gradually and that is the result of national law reform rather than imposition - but it is of course often brought about or even necessitated by decisions of the European Courts and by other institutional influences. The aim of the final volume is to draw together the information and analysis of the first three volumes (and other sources), to highlight developments and trends, and to provide an outlook on the future development of European family law. 